\title{
PTGES2 wt Allele
}

National Cancer Institute

\section{Source}

National Cancer Institute. PT GES2 wt Allele. NCI Thesaurus. Code C105115.

Human PT GES2 wild-type allele is located in the vicinity of $9 q 34.11$ and is approximately 8 $\mathrm{kb}$ in length. This allele, which encodes prostaglandin E synthase 2 protein, is involved in both transcriptional activation and the production of prostaglandin E2. 